\title{
Ylf-leder med ny roman
}

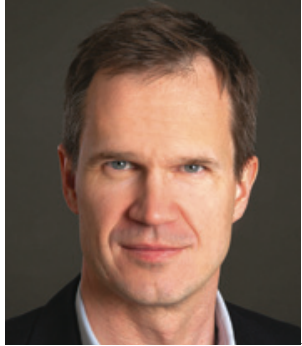

Christer Mjåset. Foto:

Kagge forlag
Spesialist i nevrokirurgi, leder i Yngre legers forening (Ylf) og forfatter Christer Mjåset (f. 1973) har nylig utgitt en ny roman - Det er du som er Bobby Fischer. På nettsidene til Kagge forlag kan vi lese at romanen handler om en 40 år gammel mann som er tvunget til å se tilbake på noe som har plaget ham hele livet. En ung jente forsvant, og noe annet gikk forferdelig galt. Hva har han og kameratene egentlig vært med på? Mjåset er selv oppvokst på Lillehammer, der romanens handling utspiller seg.
Han har tidligere utgitt to novellesamlinger og to romaner, Legen som visste for mye (2008) og Hvite ravner (2012), på Gyldendal forlag. Begge romanene er anmeldt i Tidsskriftet.

Gunn Marit Seberg

Tidsskriftet 